\title{
Examination of Factors Relative to the Intention to Recycle
}

\author{
${ }^{1}$ Lili ZHENG, ${ }^{2}$ Michel PLAISENT, ${ }^{3}$ Asli Gul ONCEL and ${ }^{4}$ Prosper BERNARD \\ ${ }^{1}$ La Rochelle Business School - Excelia Group, La Rochelle, France \\ ${ }^{2}$ University of Quebec in Montreal, Montreal, Canada \\ ${ }^{3}$ Galatasaray University, İstanbul, Turkey \\ ${ }^{4}$ University of Quebec in Montreal, Montreal, Canada
}

Correspondence should be addressed to: Michel PLAISENT; michel.plaisent@uqam.ca

Received date:17 March 2021; Accepted date:10 July 2021; Published date 3 February 2022

Academic Editor: Tijani Amara

Copyright (C) 2022. Lili ZHENG, Michel PLAISENT, Asli Gul ONCEL and Prosper BERNARD. Distributed under Creative Commons Attribution 4.0 International CC-BY 4.0

\begin{abstract}
This literature research paper focuses on human factors related to electronic waste (ewaste). From an analysis of the two last decades of academic literature on e-waste, a list of variables emerges as a convenient way to identify concerns and topics judged relevant, namely: awareness, attitudes and behaviors, incentives and deterrents, and mobile phone disposal motives. From this first global panorama of research conducted in 17 countries, the authors suggest paying more specific attention to the factors leading to the intention to dispose of mobile phones in respect of the environment and propose a predictive framework to better understand the process. The framework is based on the theory of planned behavior and augmented by background factors, namely culture, since the situation is different in each country. This study is the first step in a wider research endeavor that will include an empirical validation of the framework for a better understanding of the forces engaged in the context of mobile phone disposal, which is, at least in universities, a major aspect of e-waste.
\end{abstract}

Keywords: e-waste, recycling, mobile phone, intention

Cite this Article as: Lili ZHENG, Michel PLAISENT, Asli Gul ONCEL and Prosper BERNARD (2022)," Examination of Factors Relative to the Intention to Recycle " International Journal of Renewable Energy and Biofuels, Vol. 2022 (2022), Article ID 694535, DOI: 10.5171/2022. 694535 


\section{Introduction}

Environmental pollution is becoming a high-priority concern, as it threatens the natural resources of many countries. The following principle was declared at the United Nations Conference on the Human Environment, also known as the Stockholm Conference, in 1972: "Man has the fundamental right to freedom, equality and adequate conditions of life, in an environment of a quality that permits a life of dignity and well-being" (United Nations, 1972). The Declaration accepts that environmental protection is a precondition to the enjoyment of internationally guaranteed human rights (Öncel \& Tzanakis, 2018). The European Union (EU) has another important set of environmental standards. Article 191 of the Treaty on the Functioning of the European Union states that "Union policy on the environment shall contribute to pursuit of the following objectives: (a) preserving, protecting and improving the quality of the environment, (b) protecting human health, (c) prudent and rational utilization of natural resources, (d) promoting measures at international level to deal with regional or worldwide environmental problems, and in particular combating climate change" (European Commission, 2020). The second principle of the Stockholm Conference states that "The natural resources of the earth, including the air, water, land, flora and fauna and especially representative samples of natural ecosystems, must be safeguarded for the benefit of present and future generations through careful planning or management, as appropriate" (UN Framework Convention on Climate Change [UNFCCC], 2018).

In this context, electronic waste (e-waste) pollution is expected to play an important role in the ecosystem and to highlight the need for responsible technology (Jirotka \& Stahl, 2020). The main types of pollution areair, soil, water, noise and light pollution. E-waste is an emerging type of pollutant, defined as the various forms of electrical and electronic material that have stopped being of value to their users or no longer satisfy their original purpose. EU directives classify e-waste into 10 categories (Gill, 2010). Waste electrical and electronic equipment (WEEE) is defined as a mixture of materials and components that originated from mobile phones, computers and many more types of electronic equipment (Zhang, 2011). The first WEEE Directive (Directive 2002/96/EC) entered into force on February 13, 2003 (European Commission, 2003), but the European Commission later proposed revising the Directive in order to tackle the fast-increasing waste stream. WEEE Directive 2012/19/EU entered into force on August 13, 2012 and has been considered operative since February 2014 (European Commission, 2012). It should also be noted that China had established different types of policy, starting in 2000, as preliminary steps before the Chinese WEEE Directive came into force in January 2011 (China State Council, 2011).

This paper provides a panorama of the most important research conducted during the two last decades on e-waste and its disposal in order to identify the main human factors related to e-waste and recycling and, more specifically, those relative to mobile phones. A number of variables were found to influence the process: awareness, actual motives for change and disposal method, attitudes and other factors potentially explaining the intention to recycle, and incentives and deterrents to recycling. The role of culture is also mentioned, as well as other personal background factors. In order to provide a global view of these variables, a framework is proposed to identify and integrate the approaches and findings of the research. This framework will be tested empirically in a second phase of this research.

Robinson et al. (2018) focus on the Higher Education sector as an important source of interest in terms of a population of thousands of millions of people, economic impacts and social influence. This is why 
this research has a bias toward studying students, as a relevant group of participants in this micro-society who share characteristics of interest and behavior. Ramzan et al. (2019) further suggest that young consumers are representative of future society, as they are considered to be a technology-driven generation.

\section{Literature Review of Research on Human Factors Relative to Recycling}

\section{Background Factors}

Many factors are described in the e-waste literature of recycling motives, methods, incentives and deterrents. This section presents these variables as they have the potential to affect people's intentions and consequent behavior.

\section{Mobile Phone Disposal Methods}

Li et al. (2012) conducted a study among 100 students at Hebei University, of which $22 \%$ reported replacing their phone at least once per year. A study of 2287 students from five UK universities carried out by Ongondo and Williams (2011) reported that one third of the students also change their phone at least once a year. Most of the studies report responsible behavior with regard to the environment, since respondents either keep, donate or dispose of their phones through recycling or exchange, except for a relatively low percentage of disposal with mixed waste, as can be seen in Table 1 .

Table 1: Mobile phone disposal methods

\begin{tabular}{|c|c|}
\hline Method & Author \\
\hline $\begin{array}{l}\text { Stock home (keep for } \\
\text { storage or other } \\
\text { usage) }\end{array}$ & $\begin{array}{l}\text { Arain et al., } 2020 \text { (25\%); Bai et al., } 2018 \text { (79\%); Borthakur \& Singh, } \\
2020(50 \%) \text {; Cai et al., } 2020 \text { (54\%); Damke et al., } 2018 \text { (49\%); Li et al., } \\
2012(64 \%) \text {; Ongondo \& Williams, 2011; Priya \& Christo Frenny, } 2018 \\
\text { (48\%); Ramzan et al., } 2019 \text { (57\%); Yin et al., } 2014 \text { (47\%); Ylä-Mella et } \\
\text { al., } 2015\end{array}$ \\
\hline $\begin{array}{l}\text { Given to a } \\
\text { relative/friend }\end{array}$ & $\begin{array}{l}\text { Arain et al., } 2020(42 \%) \text {; Bai et al., } 2018 \text { (36\%); Borthakur \& Singh, } \\
2020(45 \%) \text {; Cai et al., } 2020(7 \%) \text {; Damke et al., } 2018 \text { (25\%); Li et al., } \\
2020(20 \%) \text {; Ongondo \& Williams, 2011; Xu et al., 2014; Ylä-Mella et } \\
\text { al., } 2015\end{array}$ \\
\hline Sold as second-hand & $\begin{array}{l}\text { Arain et al., } 2020 \text { (11\%); Bai et al., } 2018 \text { (8.5\%); Borthakur \& Singh, } \\
2020 \text { (30\%); Cai et al., } 2020(15 \%) \text {; Xu et al., 2014; Ying et al., } 2014 \\
(12.5 \%) \text {; Ylä-Mella et al., } 2015\end{array}$ \\
\hline $\begin{array}{l}\text { Sold or exchanged to } \\
\text { a mobile phone dealer }\end{array}$ & $\begin{array}{l}\text { Arain et al., } 2020 \text { (9\%); Bai et al., } 2018 \text { (7\%); Borthakur \& Singh, } 2020 \\
(28 \%) \text {; Cai et al., } 2020(6 \%) \text {; Damke et al., } 2018 \text { (15\%); Ramzan et al., } \\
2019 \text { (22\%); Xu et al., 2014; Ying et al., } 2014 \text { (6.5\%); Ylä-Mella et al., } \\
2015\end{array}$ \\
\hline Donated to charity & Bai et al., 2018; Li et al., 2020 (40\%); Ongondo \& Williams, 2011 \\
\hline Repaired and donated & Chen \& Yee, 2011; Ying et al., 2014 (24\%) \\
\hline $\begin{array}{l}\text { Disposed of with } \\
\text { mixed waste }\end{array}$ & $\begin{array}{l}\text { Arain et al., } 2020 \text { (25\%); Cai et al., } 2020 \text { (7\%); Priya \& Christo Frenny, } \\
2018 \text { (49\%); Xu et al., 2014; Ying et al., } 2014 \text { (7\%); Ylä-Mella et al., } \\
2015\end{array}$ \\
\hline $\begin{array}{l}\text { Sold to an informal } \\
\text { recycler }\end{array}$ & Ramzan et al., 2019 (18\%) \\
\hline $\begin{array}{l}\text { Taken to a recycling } \\
\text { center }\end{array}$ & $\begin{array}{l}\text { Ongondo \& Williams, 2011; Priya \& Christo Frenny, } 2018 \text { (22\%); Xu et } \\
\text { al., 2014; Ylä-Mella et al., } 2015\end{array}$ \\
\hline
\end{tabular}

\section{Motives for Changing Phones}

It is important to gain a better understanding of the factors that guide people in their actions and the influences that prevail in their intention to recycle. An examination of the motives for changing phones reveals that these factors are mostly functional, rather than related to consumerism alone, as can be seen in Table 2. 
Table 2: Motives for changing phones

\begin{tabular}{|l|l|}
\hline $\begin{array}{l}\text { Reason for } \\
\text { changing/replacing }\end{array}$ & \multicolumn{1}{|c|}{ Author } \\
\hline Broken & $\begin{array}{l}\text { Bai et al., 2018 (38\%); Cai et al., 2020 (42\%); Chen \& Lee, } \\
\text { 2011; Damke et al., 2018 (54\%); Li et al., 2020 (66\%); } \\
\text { Ongondo \& Williams, 2011; Xu et al., 2014; Ylä-Mella et al., } \\
2015\end{array}$ \\
\hline Poor function & $\begin{array}{l}\text { Bai et al., 2018 (45\%); Damke et al., 2018 (23\%); Li et al., } \\
2020 \text { (41\%); Ylä-Mella et al., 2015 }\end{array}$ \\
\hline Stolen & Li et al., 2020 (37\%) \\
\hline Old style & $\begin{array}{l}\text { Bai et al., 2018 (9\%); Damke et al., 2018 (15\%); Li et al., 2020 } \\
\text { (32\%); Ongondo \& Williams, 2011; Xu et al., 2014 }\end{array}$ \\
\hline Lost & Bai et al., 2018 (6\%); Damke et al., 2018 (5\%) \\
\hline Cannot upgrade & Bai et al., 2018; Cai et al., 2020 (50\%); Chen \& Lee, 2011 \\
\hline $\begin{array}{l}\text { Network operator or provider } \\
\text { contract } \\
\text { replacement/upgrade }\end{array}$ & $\begin{array}{l}\text { Ongondo \& Williams, 2011; Xu et al., 2014; Ylä-Mella et al., } \\
\text { 2015 }\end{array}$ \\
\hline Newer product is cheap & Chen \& Lee, 2011 \\
\hline Longer battery life & Ongondo \& Williams, 2011 \\
\hline More image and music storage & Ongondo \& Williams, 2011 \\
\hline
\end{tabular}

\section{Motives and Incentives to Recycle}

Ylä-Mella et al. (2015) report that the main motives for recycling that are related to the environment are resource efficiency, environmental protection, health issues and economic value (i.e., the compensation given for a phone); this is perhaps because the students are not rich, but compensations of many types are stronger motivators mentioned in the literature. Incentives to recycle are presented in Table 3.

Table 3: Types of incentives to recycle

\begin{tabular}{|l|l|}
\hline $\begin{array}{c}\text { Cash, voucher or amenities } \\
\text { (e.g., free SNMS or } \\
\text { downloads) }\end{array}$ & \multicolumn{1}{c|}{$\begin{array}{c}\text { Arain et al., 2020; Chen \& Yee, 2011; Li et al., 2020 (81\%); } \\
\text { Ongondo \& Williams, 2011 }\end{array}$} \\
\hline Air time & Li et al., 2020 (58\%); Ongondo \& Williams, 2011 \\
\hline Data service & Li et al., 2020 (81\%) \\
\hline Collecting price & Chen \& Yee, 2011; Ongondo \& Williams, 2011; Qu et al., 2019 \\
\hline $\begin{array}{l}\text { Compensation mode (e.g., } \\
\text { cash vs coupon) }\end{array}$ & Bai et al., 2018; Qu et al., 2019 \\
\hline Data safety insurance & Bai et al., 2018; Qu et al., 2019 \\
\hline Trust in the recycling party & Bai et al., 2018 \\
\hline Prize draw & Li et al., 2020 (17\%); Ongondo \& Williams, 2011 \\
\hline
\end{tabular}

\section{Deterrents to Recycling}

Many factors are mentioned as deterrents to recycling in several studies, as summarized in Table 4. 
Table 4: Deterrents

\begin{tabular}{|l|l|}
\hline Fear of information leakage & \multicolumn{1}{|c|}{$\begin{array}{l}\text { Ongondo \& Williams, 2011; Qu et al., 2019; Ramzan et al., } \\
\text { 2019 (11\%); Xu et al., 2014 }\end{array}$} \\
\hline $\begin{array}{l}\text { Low awareness and low } \\
\text { information of channels }\end{array}$ & $\begin{array}{l}\text { Bai et al., 2018; Ramzan et al., 2019 (21\%); Ylä-Mella et al., } \\
2015\end{array}$ \\
\hline $\begin{array}{l}\text { Not knowing how to dispose } \\
\text { of a phone }\end{array}$ & Ongondo \& Williams, 2011; Qu et al., 2019 \\
\hline $\begin{array}{l}\text { Do not see the importance of } \\
\text { it }\end{array}$ & Chen \& Yee, 2011 \\
\hline Absence of laws/regulations & Ramzan et al., 2019 (8\%); Xu et al., 2014 \\
\hline $\begin{array}{l}\text { Weak environmental } \\
\text { awareness }\end{array}$ & Xu et al., 2014 \\
\hline Low collecting price & Qu et al., 2019 \\
\hline Fees to pay for disposal & Bai et al., 2018; Cai et al., 2020; Damke et al., 2018 \\
\hline Inconvenience & Qu et al., 2019; Ramzan et al., 2019 (16\%); Xu et al., 2014 \\
\hline $\begin{array}{l}\text { Collecting } \\
\text { distance/convenience }\end{array}$ & $\begin{array}{l}\text { Bai et al., 2018; Ongondo \& Williams, 2011; Qu et al., 2019; } \\
\text { Ylä-Mella et al., 2015 }\end{array}$ \\
\hline $\begin{array}{l}\text { Lack of knowledge of } \\
\text { recycling channels }\end{array}$ & Bai et al., 2018; Ylä-Mella et al., 2015 \\
\hline İndifference & Qu et al., 2019 \\
\hline Do not think it has any value & Ongondo \& Williams, 2011 \\
\hline Other specified & Qu et al., 2019 \\
\hline
\end{tabular}

Demographics

Many studies report on differences observed in relation to demographic variables, as summarized in Table 5.

Table 5: Demographic variables

\begin{tabular}{|l|l|}
\hline Gender (women are more concerned) & Favot \& Grassetti, 2017 \\
\hline $\begin{array}{l}\text { Age (younger people are less informed and } \\
\text { sensitive) }\end{array}$ & Nnorom et al., 2009; Saphores et al., 2006 \\
\hline $\begin{array}{l}\text { Revenue (wealthier people are positive } \\
\text { toward paying) }\end{array}$ & Cai et al., 2020; Nnorom et al., 2009 \\
\hline
\end{tabular}

\section{Cultural and Psychological Factors}

\section{Knowledge, Awareness and Perceived Usefulness}

Sadik et al. (2017) focused on aspects of awareness in carrying out a survey among students from three different cities in Bangladesh in order to learn about their awareness of e-waste management. The researchers gathered questionnaires from 1055 students of classes 10 to 12 and from first- and second-year university students in the age group of 16-22. The survey results showed that the students concerned were not aware of or concerned about e-waste and managed it like ordinary waste.
Ylä-Mella et al. (2015) focused on consumers' awareness of mobile phone waste management in the city of Oulu in Finland, which has a population of over 200,000 . The survey aimed to examine recycling behavior and awareness. One of the findings was that the respondents to the survey stated they had knowledge of WEEE but only half of them respected it. Nnorom et al. (2009) carried out a survey with 1000 pedestrians near a Nigerian university to study the respondents' willingness to pay extra $(10 \%, 20 \%$ or more) in consideration of the environment and found that willingness grew with age, revenue and awareness and concern about the deterioration of the environment. In a 
study of 137 students in Portugal, Marques and da Silva (2017) found that $40 \%$ were aware of e-waste, $35 \%$ were careful and $66 \%$ were aware of the consequences in terms of natural resources and environment; $75 \%$ ignored the law, although 35\% knew about an eco-tax; and $81 \%$ ignored the national entity charged with the management and disposal of ewaste.

Analyzing data from a survey collected from 850 students from high-ranking educational institutions in China, Ramzan et al. (2019) reported that students had no $(20 \%)$ or low $(61 \%)$ awareness of e-waste and no $(30 \%)$ or low (56\%) awareness of recycling; $40 \%$ had never or only a little $(53 \%)$ participated in recycling in the past; $66 \%$ had no idea of the relevant laws, while $23 \%$ had only a low awareness; and $42 \%$ ignored recycling programs and $55 \%$ had only a low awareness of the initiatives. In another study conducted in China, a survey of 474 families living in a city reported that $76 \%$ of the respondents were aware of the threat to the environment due to the improper processing of e-waste, although only $38 \%$ were willing to pay a fee (Cai et al., 2020).

A study of 430 consumers in a Brazilian city reported that a majority of the respondents were not aware of the law regulating electronic devices due to a lack of advertising, $72 \%$ were not aware of the law enforcing the recycling of mobile phones, although $71 \%$ knew they contain toxic substances (Damke et al., 2018).

A survey of 150 students at an IT college conducted by Chen and Yee (2011) in Malaysia found the following results: one third of the respondents knew of the existence of collectors; around one third had no idea about e-waste, while 55\% had little awareness and only $11 \%$ had a clear understanding; and one third did not see the importance of recycling. These results indicate a lack of awareness of recycling and its importance.

\section{Culture}

An examination of the relevant literature shows that research on e-waste has been conducted all over the world and on all continents. The classification of articles focusing on the human aspects of mobile phones more specifically reveals that these studies were carried out in at least 17 countries, with China leading in terms of the quantity of publications, as seen in Table 6.

\section{Table 6: Distribution of articles by origin of the data}

\begin{tabular}{|l|l|}
\hline Australia & Davis \& Herat, 2010 \\
\hline Bangladesh & Sadık et al., 2017 \\
\hline Brazil & Damke et al., 2018 \\
\hline China & $\begin{array}{l}\text { Bai et al., 2018; Cai et al., 2020; Cheng et al., 2020; Li et al., 2012; Liang \& } \\
\text { Sharp, 2016; Qu et al., 2019; Ramzan et al., 2019; Xu et al., 2014; Yin et al., } \\
\text { 2014 }\end{array}$ \\
\hline Finland & Ylä-Mella et al., 2015 \\
\hline India & Borthakur \& Singh, 2020; Priya \& Christo Frenny, 2018 \\
\hline Iran & Mirgerami et al., 2018 \\
\hline Italy & Favot \& Grassetti, 2017 \\
\hline Laos & Liang \& Sharp, 2016 \\
\hline Malaysia & Ahmad \& Nordin, 2014; Chen \& Yee, 2011) \\
\hline Nigeria & Nnorom et al., 2009 \\
\hline Poland & Nowakowski, 2016 \\
\hline Portugal & Marques \& da Silva, 2017 \\
\hline Romania & Delcea et al., 2020 \\
\hline Thailand & Liang \& Sharp, 2016 \\
\hline UK & Ongondo et al., 2011; Pierron et al., 2017 \\
\hline USA & Arain et al., 2020; Saphores, 2006 \\
\hline
\end{tabular}




\section{Convenience (Ease of Disposal)}

Following a mail survey of 3000 Californian households, Saphores et al. (2006) reported that older people were concerned with the convenience of disposal and that the availability of collectors was a prerequisite to any action. A survey addressed to councils in Australia revealed that the lack of disposal facilities was one of the main constraints to e-waste management, that the public lacked awareness, the cost of disposal should be directed to consumers, and that a law should be adopted to deal with that concern (Davis \& Herat, 2010). In a study covering 7 years of data from 20 regions in Italy, Favot and Grassetti (2017) concluded that the presence of collecting points is a crucial factor in explaining the collection of e-waste.

Knowledge of how to recycle is also important. Arain et al. (2020) distributed a questionnaire to staff and students at a US university and received 1560 responses. They found that $44 \%$ of the respondents never recycle $(80 \%$ of them claimed they did not know where and how); that convenience of disposal (87\%) and

knowledge were critical to explaining respondents' behavior; and that low cost would encourage them to recycle but $85 \%$ would prefer a reward.

In a study conducted by Borthakur and Singh (2020) in New Delhi with 334 students, $69 \%$ pretended to be willing to recycle but $88 \%$ did not know how. In Iran, Mirgerami et al. (2018) found that mobile phones were among the electronic devices most frequently sent as waste, in a study that concluded the need for waste processing infrastructure in the country.

\section{Laws and Rules as Sources of Control Belief}

As an example of the diversity of approaches due to country and culture, Liang and Sharp (2016) administered a survey in three countries (Thailand, Laos and China) to two subgroups (retailers and consumers) and interviewed members of three other subgroups (manufacturers, ewaste recyclers and policy makers). They gathered information on policies, which they measured using the knowledge of the respondents of e-waste laws, their willingness to comply, and concern about the environment and how to improve its condition. They found significant differences between countries, Lao receiving the highest score for both policies and practices. China received the highest score for a combine measure of policy, process and practices.

Studying the situation with regard to ewaste in Poland, Nowakowsky (2016) reported a $40 \%$ rate of collection of devices for recycling, which was due to new programs to process waste equipment and to the effort of information directed toward retailers, manufacturers and consumers. A study by Laroche et al. (2002) also showed the importance of culture in relation to environmental knowledge, attitude and behavior. Theory of Planned Behavior: Attitudes,
Beliefs, Norms and Intention

An adaptation of the theory of planned behavior (TPB) (Ajzen, 1991) in order to predict the intention to recycle was made by $\mathrm{Xu}$ et al. (2014), with legal advocacy moderating the impact of subjective norms, environmental knowledge moderating the effect of attitude to recycling, and recycling experience moderating the perceived behavioral control. Their model was tested with 196 residents recruited in eight supermarkets in Tianjin in China. They found that concern for the environment (recycling experience and attitude toward recycling moderated by environmental knowledge) is critical to the intention to recycle and that subjective norms (moderated by legal advocacy) as well as behavioral (government) control can be helpful in understanding the recycling intention.

Cheng et al. (2020) used a modified version of the TPB to examine 358 Taipei consumers' attitudes and intentions with regard to recycling mobile phones. They 
tested with success a model to predict consumer intention to recycle mobile phones as a consequence of subjective norms from reference groups, attitude toward recycling (determined by social and individual relative advantages and perceived cost) and perceived behavior control (from self-efficacy and facilitating conditions).

A systematic review of the literature (1975-2019) conducted by Concari et al. (2020) showed that among the 669 papers considered, most referred to a relatively small number of theories: the theory of reasoned action (Fishbein \& Ajzen, 1975), the normative action model (Wang et al.), the TPB (Ajzen, 1991), and value-beliefnorm theory (Stern, 2000), and that some of the theories are merged. Based on a survey of 532 respondents from several social media platforms, Delcea et al. (2020) validated a model with LISREL in which the intention to recycle is determined by attitude, awareness, self-efficacy, responsibility, social norms, social influence, and social media. Intention is translated into behavior if moderated by convenience and government measures.

\section{Proposal of a Research Model for Predicting Intention to Recycle}

The literature review conducted above can be summarized into a meaningful framework, presented below, in which situational and background factors are grouped as variables to control, and personal factors, namely culture, are expected to have a link with attitudes toward recycling behavior; in a similar manner, ease of recycling and knowledge of environmental fragility and the need to protect the environment are expected to be related to attitudes. The diagram below also contains an application of the classic theory of planned behavior to explain the intention to recycle.

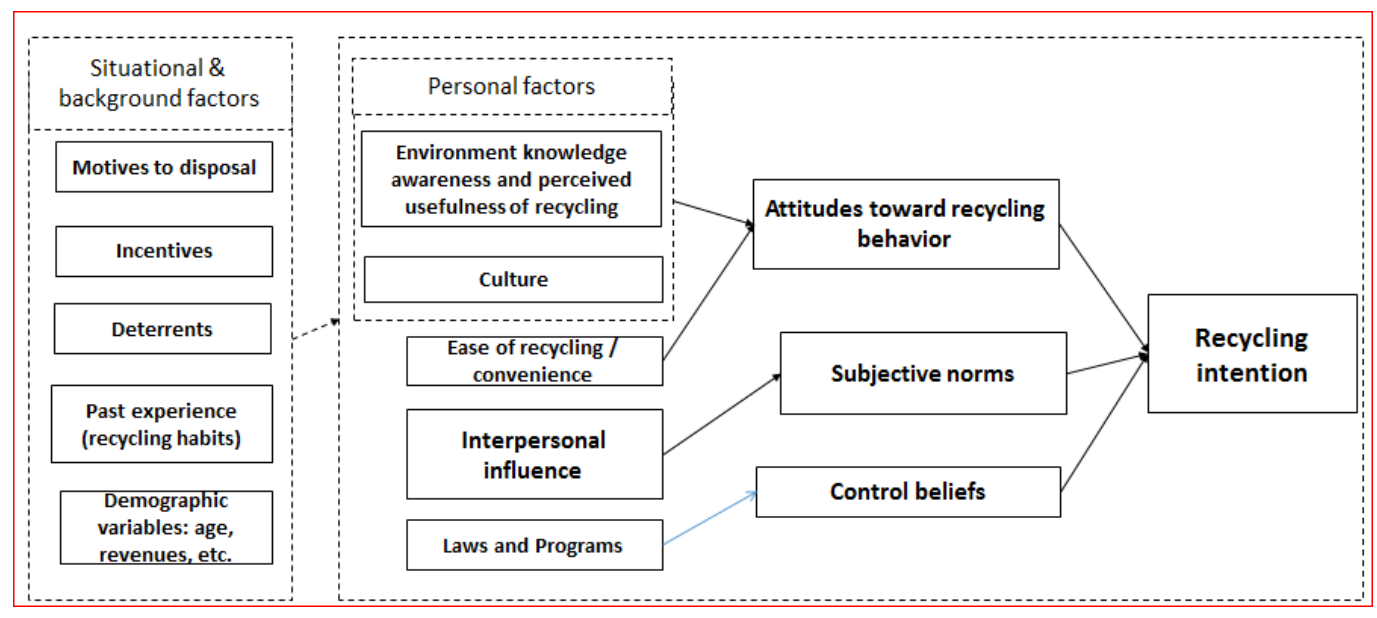

Figure: Proposed research model for predicting intention to recycle.

\section{Conclusion}

Given the importance of environmental strategies and policies on the short and long term protection of the resources of mother Earth and future people prosperity, a severe change of mind and behavior is needed by all and mostly the future leaders of society, i.e. the actual students. Environmental policies enable the world's economies to protect natural resources, safeguard health, and support the prosperity of individuals. Ecological approaches and enactment secure common natural surroundings but cannot guarantee appropriate e-waste transfer unless each individual feels concern with regard to his or her own disposal of unwanted devices. This paper presented a panorama of the ewaste situation from the study of main recent international academic publications. This allowed a schematic representation of 
individuals' actual behavior, the human factors involved in the intention of those individuals to comply with ecological norms, and what influences their intention to comply. This overview of the literature favored the emergence of a framework that will form the grounding for a second study based on an empirical approach to validate the model developed and its ability to predict individual intention to comply. The next conference will be an opportunity to present the results of this second phase of the research.

\section{References}

- Ajzen, I. (1991). 'The Theory of Planned Behavior'. Organizational Behavior and Human Decision Processes, Vol. 50 Iss. 2, pp. 179-211. https://doi.org/10.1016/07495978(91)90020-T.

- Arain, A.L., Pummill, R., Adu-Brimpong, J., Becker, S., Green, M., Ilardi, M., Van Dam, E. and Neitzel, R.L. (2020). 'Analysis of E-Waste Recycling Behavior Based On Survey At A Midwestern US University', Waste Management, Vol. 105, pp. 119-127. https://doi.org/10.1016/j.wasman.20 20.02 .002

http://www.sciencedirect.com/scienc e/article/pii/S0956053X20300581.

- $\quad$ Bai, H., Wang, J. and Zeng, A.Z. (2018). 'Exploring Chinese Consumers' Attitude And Behavior Toward Smartphone Recycling', Journal of Cleaner Production, Vol. 188, pp. 227236.

https://doi.org/10.1016/j.jclepro.201 8.03.253

(http://www.sciencedirect.com/scienc e/article/pii/S095965261830934X).

- Borthakur, A. and Singh, P. (2020). 'The Journey From Products To Waste: A Pilot Study On Perception And Discarding of Electronic Waste In Contemporary Urban India', Environmental Science and Pollution Research, Vol. 24 No. 17. https://doi.org/10.1007/s11356-02009030-6.

- $\quad$ Cai, K., Song, Q., Peng, S., Yuan, W., Liang, Y. and Li, J. (2020). 'Uncovering Residents' Behaviors, Attitudes, And
WTP For Recycling E-Waste: A Case Study of Zhuhai City, China', Environmental Science and Pollution Research, Vol. 27, pp. 2386-2399. https://doi.org/10.1007/s11356-01906917-x.

- Chen, L.F. and Yee, H.W. (2011). 'EWaste Management: Are We Ready For It? A Study On The Awareness Of COIT Students Toward E-Waste Management', ICIMU 2011: Proceedings of the 5th International Conference on Information Technology \& Multimedia, Kuala Lumpur, 2011, pp. 1-5. doi: 10.1109/ICIMU.2011.6122729.

- Cheng, M., Hung, S., Tsai, H. and Chou, Y. (2020). 'Fostering Environmentally Responsible Consumer Behavior: A Hierarchical Approach Toward Smartphone Recycling', IEEE Transactions on Engineering Management. doi: 10.1109/TEM.2020.3007605.

- China State Council (2011). 'The Regulations For The Administration of The Recovery And Disposal of Waste Electrical And Electronic Products'. State Council Document No. 551. http://www.gov.cn/zwgk/200903/04/content_1250419.htm.

- Concari, A., Kok, G. and Martens, P. (2020). 'A Systematic Literature Review Of Concepts And Factors Related To Pro-Environmental Consumer Behaviour In Relation To Waste Management Through An Interdisciplinary Approach', Sustainability, Vol. 12 No. 11, p. 4452. https://doi.org/10.3390/su12114452.

- Damke, L.I., Arenhardt, D.L., Dill, R.A., Rodrigues, L.A. and Trevisan, M. (2018). 'Inappropriate Disposal of Cellphones Affect Environmental Quality-An Analysis of Brazilian Users', Environmental Quality Management, Vol. 28 No. 2, pp. 137154. https://doi.org/10.1002/tqem.21601.

- Davis, G. and Herat, S. (2010). 'Opportunities And Constraints For Developing A Sustainable E-Waste Management System At Local Government Level In Australia', Waste Management \& Research, Vol. 28 No. 8, pp. 705-713. 
https://doi.org/10.1177/0734242X09

343008.

- Delcea, C., Crăciun, L., Ioanăș, C., Ferruzzi, G. and Cotfas, L.-A. (2020). 'Determinants of Individuals' E-Waste Recycling Decision: A Case Study From Romania', Sustainability, Vol. 12 No. 7, p.

2753. https://doi.org/10.3390/su12072753.

- European Commission (2003). Directive 2002/96/EC Of The European Parliament And of The Council of 27 January 2003 On Waste Electrical And Electronic Equipment (WEEE). https://eurlex.europa.eu/resource.html?uri=cellar :ac89e64f-a4a5-4c13-8d96-

1fd1d6bcaa49.0004.02/DOC_1\&format $=$ PDF.

- European Commission (2012). Directive 2012/19/Eu Of The European Parliament And of The Council Of 4 July 2012 On Waste Electrical And Electronic Equipment (WEEE) (Recast) (Text With Eea Relevance).

https://eurlex.europa.eu/LexUriServ/ LexUriServ.do?uri=0J:L:2012:197:003 8:0071:en:PDF.

- European Commission (2020). Environmental Assessments Of Plans, Programs And Projects: Rulings Of The Court of Justice of The European Union.

http://ec.europa.eu/environment/eia/ pdf/EIA_rulings_web.pdf.

- Favot, M. and Grassetti, L. (2017). 'EWaste Collection In Italy: Results From An Exploratory Analysis', Waste Management, Vol. 67, pp. 222-231. https://doi.org/10.1016/j.wasman.20 17.05.026.

(http://www.sciencedirect.com/scienc e/article/pii/S0956053X17303495).

- Fishbein, M. and Ajzen, I. (1975). Belief, Attitude, Intention, And Behavior: An Introduction To Theory And Research. Reading, MA: AddisonWesley.

- Gill, G.N. (2010). 'A Green Tribunal for India'. Journal of Environmental Law, Vol. 22 Iss. 3, pp. 461474. https://doi.org/10.1093/jel/eqq0 14
- Jirotka, M. and Bernd Carsten Stahl (2020). 'The Need For Responsible Technology', Journal of Responsible Technology. 2020 Oct. ; doi: 10.1016/j.jrt.2020.100002

- $\quad$ Laroche, M., Tomiuk, M.-A., Bergeron, J. and Barbaro-Forleo, G. (2002). 'Cultural Differences In Environmental Knowledge, Attitudes, And Behaviours of Canadian Consumers', Canadian Journal of Administrative Sciences, Vol. 19 No. 3, pp. 267-283.

- Li, B., Yang, J., Song, X. and Lu, B. (2012). 'Survey On Disposal Behaviour And Awareness of Mobile Phones In Chinese University Students', Procedia Environmental Sciences, Vol. 16, pp. 469-476.

https://doi.org/10.1016/j.proenv.201 2.10.064.

- Liang, L. and Sharp, A. (2016). 'Development of An Analytical Method For Quantitative Comparison Of The EWaste Management Systems In Thailand, Laos, And China', Waste Management \& Research, Vol. 34 No. 11, pp. 1184-1191. https://doi.org/10.1177/0734242X16 662333

- $\quad$ Marques, C.G. and da Silva, V.G. (2017). 'E-Waste Management In Portugal: Legislation, Practices And Recommendations', Journal of Information Systems Engineering \& Management, Vol. 2 No. 4, pp. 22-27. https://doi.org/10.20897/jisem.20172 2.

- Mirgerami, S.M., Yaftian, M.R., Parizanganeh, A.H. and Zamani, A.A. (2018). 'The Status Of Electronic Waste In Iran', Journal of Human, Environment and Health Promotion, Vol. 4 No. 2, pp. 55-63. http://zums.ac.ir/jhehp/article1-169-en.html.

- Nnorom, I.C., Ohakwe, J. and Osibanjo, 0. (2009). 'Survey Of Willingness of Residents To Participate In Electronic Waste Recycling In Nigeria-A Case Study of Mobile Phone Recycling', Journal of Cleaner Production, Vol. 17 Iss. 18, pp. 1629-1637. https://doi.org/10.1016/j.jclepro.200 9.08.009 
(http://www.sciencedirect.com/scienc e/article/pii/S0959652609002534).

- Nowakowski, P. (2016). 'The Influence of Residents' Behaviour On Waste Electrical And Electronic Equipment Collection Effectiveness', Waste Management \& Research, Vol. 34 No. 11, pp. 1126-1135. https://doi.org/10.1177/0734242X16 669997.

- Öncel, A.G. and Tzanakis, T. (2018). 'Legal And Statistical Framework of Climate Change From The EU And International Point of View'.Athens Journal of Sciences, Vol. 5 Iss. 4, pp. 307-328.

https://doi.org/10.30958/ajs.5-4-1.

- Ongondo, F.O. and Williams, I.D. (2011). 'Greening Academia: Use And Disposal of Mobile Phones Among University Students', Waste Management, Vol. 31 Iss. 7, pp. 16171634.

https://doi.org/10.1016/j.wasman.20 11.01.031.(http://www.sciencedirect.c om/science/article/pii/S0956053X11 000663).

- Ongondo, F.O., Williams, I.D. and Whitlock, G. (2011). 'Distinct Urban Mines: Exploiting Secondary Resources In Unique Anthropogenic Spaces'. Waste Management, Vol. 45, pp. 4-9. https://doi.org/10.1016/j.wasman.20 15.05.026.

http://www.sciencedirect.com/scienc e/article/pii/S0956053X15003803).

- $\quad$ Pierron, X., Williams, I.D., Shaw, P.J. and Cleaver, V. (2017). 'Using Choice Architecture To Exploit A University Distinct Urban Mine', Waste Management, Vol. 68, pp. 547-556. https://doi.org/10.1016/j.wasman.20 17.06.034

(http://www.sciencedirect.com/scienc e/article/pii/S0956053X17304749).

- $\quad$ Priya, N. and Christo Frenny, F. (2018). 'A Survey On Level Of Awareness Of EWaste Management System', International Journal of Advanced Research in Computer Science, Vol. 9 Iss. 1 , pp. 27-32. https://doi.org/10.26483/ijarcs.v9i0.5 605.

- Qu, Y., Wang, W., Liu, Y. and Zhu, Q. (2019). 'Understanding Residents'
Preferences For E-Waste Collection In China- A Case Study of Waste Mobile Phones',Journal of Cleaner Production, Vol. 228, pp. 52-62. https://doi.org/10.1016/j.jclepro.201 9.04.216

(http://www.sciencedirect.com/scienc e/article/pii/S0959652619313034).

- Ramzan, S., Liu, C., Munir, H. and Yan, X. (2019). 'Assessing Young Consumers' Awareness And Participation In Sustainable E-Waste Management Practices: A Survey Study In Northwest China', Environmental Science and Pollution Research, Vol. 26, pp. 2000320013.

https://doi.org/10.1007/s11356-01905310-y.

- Robinson, O.J., Tewkesbury, A., Kemp, S. and Williams, I.D. (2018). "Towards A Universal Carbon Footprint Standard: A Case Study of Carbon Management At Universities', Journal of Cleaner Production, Vol. 172, pp. 4435-4455.

https://doi.org/10.1016/j.jclepro.201 7.02.147

(http://www.sciencedirect.com/scienc e/article/pii/S0959652617303736).

- Sadik, M.N., Nayem Arefin, S.M. and Tabassum, M. (2017). 'A Survey On Students' Awareness About E-Waste In Bangladesh', 2nd International Conference on Electrical \& Electronic Engineering (ICEEE), Rajshahi, 27-29 December 2017, RUET, Rajshahi, Bangladesh, pp. 1-4, doi: 10.1109/CEEE.2017.8412896.

- Saphores, J.-D.M., Nixon, H., Ogunseitan, O.A. and Shapiro, A.A. (2006). 'Household Willingness To Recycle Electronic Waste: An Application To California', Environment and Behavior, Vol. 38 No. 2, pp. 183208. https://doi.org/10.1177/0013916505 279045.

- Schwartz, S.H. (1977). 'Normative Influences On Altruism. In Berkowitz, L. (Ed.)', Advances in experimental social psychology (Vol. 10, pp. 221279). New York: Academic Press.

- Stern, P.C. (2000). 'New Environmental Theories: Toward A Coherent Theory of Environmentally Significant 
Behavior', Journal of Social Issues, Vol. 56 Iss. 3, pp. 407-424. https://doi.org/10.1111/00224537.00175 .

- United Nations (1972). Report of the United Nations Conference on the Human Environment. Stockholm: UN.

- United Nations Framework Convention on Climate Change (2018). UN Climate Change Annual Report 2018. https://unfccc.int/sites/default/files/r esource/UN-Climate-Change-AnnualReport-2018.pdf.

- Wang, Z., Guo, D., Wang, X., Zhang, B. and Wang, B. 'How Does Information Publicity Influence Residents' Behaviour Intentions Around E-Waste Recycling?' Resour. Conserv. Recycl. 2018, 133, 1-9.

- Xu, F., Wang, X., Sun, X. and Abdullah, A. (2014). 'Influencing Factors And Moderating Factors of Consumers' Intentions To Participate In E-Waste Recycling', 11th International Conference on Service Systems and Service Management (ICSSSM), Beijing, 2014, pp. 1-6. doi: 10.1109/ICSSSM.2014.6874096.
- Yin, J., Gao, Y. and Xu, H. (2014). 'Survey And Analysis Of Consumers' Behaviour of Waste Mobile Phone Recycling In China', Journal of Cleaner Production, Vol. 65, pp. 517-525. https://doi.org/10.1016/j.jclepro.201 3.10.006.

(http://www.sciencedirect.com/scienc e/article/pii/S0959652613006690).

- Ylä-Mella, J., Keiski, R.L. and Pongrácz E. (2015). 'Electronic waste recovery in Finland: consumers' perceptions towards recycling and re-use of mobile phones',Waste Management, Vol. 45, pp. 374-384. https://doi.org/10.1016/j.wasman.20 15.02.031

(http://www.sciencedirect.com/scienc e/article/pii/S0956053X15001348).

- Zhang, H. (2011). 'Analysis Of The "China WEEE Directive": Characteristics, Breakthroughs And Challenges of The New WEEE Legislation In China', Erasmus Mundus MSc thesis, Lund, Sweden. 